\title{
Molecules in medicine mini-review: isoforms of PI3K in biology and disease
}

\section{Bart Vanhaesebroeck • Maria A. Whitehead • Roberto Piñeiro}

UCL Cancer Institute, University College London, 72 Huntley Street, London WC1E 6BT, United Kingdom. E-mail: bart.vanh@ucl.ac.uk

\begin{abstract}
The PI3K lipid kinases are involved in signal transduction and intracellular vesicular traffic, endowing these enzymes with multiple cellular functions and important roles in normal physiology and disease. In this mini-review, we aim to distil from the vast PI3K literature the key relevant concepts for successful targeting of this pathway in disease. Of the eight isoforms of PI3K, the class I PI3Ks have been implicated in the aetiology and maintenance of various diseases, most prominently cancer, overgrowth syndromes, thrombosis, inflammation and autoimmunity, with emerging potential roles in metabolic, cardiovascular and other disorders. The development of class I PI3K inhibitors, mainly for use in cancer and inflammatory disorders, is a very active area of drug development. In 2014, an inhibitor of the p110 isoform of PI3K was approved for the treatment of some human B-cell malignancies. The key therapeutic indications of targeting each class I PI3K isoform are summarized and discussed.
\end{abstract}

Keywords PI3K . Signalling - Vesicular Traffic • Cancer • Overgrowth Syndrome - Immunity • Inflammation . Auto-immunity . Diabetes . Obesity . Metabolic syndrome $\cdot$ Pharmacological inhibitor

\section{The PI3K family}

The common and defining feature of PI3Ks is their ability to phosphorylate the 3-hydroxyl group on phosphoinositides that reside on cellular membranes. All eight mammalian PI3Ks (Figure 1) share a conserved catalytic domain but differ in their regulation and preferred lipid substrate. PI3K activity is opposed by lipid phosphatases, such as PTEN, INPPs and SHIPs (class I PI3Ks) and myotubularins (class II and III PI3Ks). Loss-of-function of these phosphatases is of key importance in some diseases, such as cancer (the PTEN and INPPs are tumour suppressors) and certain myopathies (myotubularins).

Class I PI3Ks are heterodimers formed of a regulatory and a catalytic (p110) subunit, further referred to as PI3K $\alpha, \mathrm{PI} 3 \mathrm{~K} \beta, \mathrm{PI} 3 \mathrm{~K} \delta$ and PI3K$\psi$. They are further subdivided into class IA (PI3K $\alpha, \mathrm{PI} 3 \mathrm{~K} \beta$, $\mathrm{PI} / 3 \mathrm{~K} \delta$ ) or IB (PI3KY) depending on the type of regulatory subunit present in the complex (p85 or p84/p101 for class IA and IB, respectively). All class I PI3Ks couple to cell surface receptors at the plasma membrane where, upon activation, they phosphorylate phosphatidylinositol-4,5bisphosphate $\left(\mathrm{PI}(4,5) \mathrm{P}_{2}\right)$ into the short-lived second messenger $\mathrm{PI}(3,4,5) \mathrm{P}_{3}\left(\mathrm{PIP}_{3}\right)$. Despite this apparent simplicity, the upstream activation of these isoforms is complex, and includes engagement with phosphotyrosines in receptors and adaptor proteins via the $\mathrm{SH} 2$ domains of the p85 regulatory subunit $(P I 3 K \alpha, P I 3 K \beta, P I 3 K \delta), G_{\beta \gamma}$ subunits released by activated $G$ protein-coupled receptors

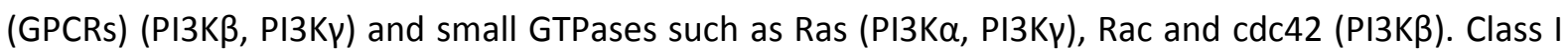
$\mathrm{PI} \mathrm{K}$ activity is transmitted into the cell through the localised accumulation of $\mathrm{PIP}_{3}$, which induces the recruitment of pleckstrin homology $(\mathrm{PH})$ domain-containing effector proteins to the plasma membrane where they are activated. These effector proteins include protein kinases, adaptor proteins and regulators of small GTPases. The serine/threonine kinase Akt/PKB, a key class I PI3K 
effector, is an important signalling node that regulates cell survival, cell cycle, glucose metabolism, protein synthesis and migration.

Class II PI3Ks (PI3K-C2 $\alpha, \mathrm{PI3K}-\mathrm{C} 2 \beta$ and PI3K-C2 $\gamma$ ) and the class III PI3K (vps34) mainly associate with intracellular membranes where they produce the lipids $\mathrm{PI} 3 \mathrm{P}$ and most likely also $\mathrm{PI}(3,4) \mathrm{P}_{2}$ (Figure 1). Their regulation is less well understood than that of class I PI3Ks, but they have been implicated in the regulation of vesicular traffic, such as in endocytosis and autophagy. The role of the class II/III PI3Ks in signal transduction by extracellular ligands is not clear, but their activities might directly or indirectly modulate such signalling.

\section{PI3K isoforms in disease}

In addition to their catalytic activity, several isoforms of PI3K and their adaptors have scaffolding functions[1,2]. In this review, we only describe the kinase-dependent functions of PI3Ks, given that these, in principle, could be regulated by small molecule pharmacological inhibitors.

At present, only the class I PI3K isoforms have been firmly implicated in disease (Table I). This is not the case for class II/III PI3Ks, and these isoforms will therefore not be discussed in detail here. Interestingly, however, organismal inactivation of the kinase activity of PI3K-C2 $\beta$ in mice has recently been reported to result in enhanced insulin sensitivity and glucose tolerance, without detectable side effects[3], indicating that this particular PI3K isoform might be a potential drug target for metabolic disorders. The class III PI3K, vps34, has been implicated in the regulation of autophagy, a process that has been associated with a spectrum of diseases ranging from cancer to neurodegeneration. This has spurred the development of vps34 inhibitors (reviewed in Ref.[4]), but the potential of vps34 inhibition in a disease context still remains to be established.

Below, we describe key features and functions of each class I PI3K isoform.

\section{PI3Ka}

$\mathrm{p} 110 \alpha$, the catalytic subunit of PI3K $\alpha$, is ubiquitously expressed. PIK3CA, the gene encoding $\mathrm{p} 110 \alpha$, is frequently amplified or somatically mutated in solid tumours/carcinoma but very rarely in soft tissue cancers/sarcoma or haematological malignancies. 'Oncogenic' PIK3CA mutations are found across the PIK3CA gene but mainly occur in hot-spots and lead to increased lipid binding and/or basal activity of $\mathrm{p} 110 \alpha$ through a multitude of mechanisms that mimic and enhance the dynamic allosteric/intramolecular events that normally activate wild-type PI3K $\alpha$ (Ref.[5]).

PIK3CA and PI3K pathway components have recently been found to be somatically mutated in a spectrum of congenital or early childhood onset human overgrowth disorders[6-10]. PI3K pathway mutations in these disorders are almost exclusively found in tissue of mesodermal origin, with overgrowth frequently observed in adipose, muscle and skeletal tissue. Interestingly, despite the PIK3CA mutations associated with overgrowth disorders being similar to those observed in cancer, individuals with this condition do not appear to be predisposed to cancer. This suggests that the context in which the PIK3CA mutations occur determines its role in disease.

The prevalence of PIK3CA mutation and amplification in cancer suggest an important role for p110 $\alpha$ in cancer development. Two recent reports[11,12] have revealed that expression of mutant Pik3ca induces multipotency in breast cancer progenitor cells, possibly contributing to intratumoural heterogeneity. At present, it is not entirely clear how critical PIK3CA alterations are in established cancer. Indeed, whereas the presence of PIK3CA mutation/amplification in cancer cell 
lines has some predictive value in determining sensitivity to PI3K inhibitors, this correlation is not absolute and other genetic parameters also control this response[13]. This is in fact not surprising given that cancer cells have multiple ways of activating the PI3K pathway, other than through mutational activation of $\mathrm{p} 110 \alpha$, including through mutation of the p85 regulatory subunits, upstream activators such as tyrosine kinases and Ras, and downstream effectors such as Akt, or by loss of the PTEN tumour suppressor. Indeed, cancer cells almost invariably "hijack" the PI3K pathway, with mutation of PIK3CA being only one of several ways of achieving this. An overview of the genomic determinants of PI3K pathway inhibitor response in cancer is given in Ref.[14].

Under normal physiological conditions, PI3K $\alpha$ is a key effector molecule in insulin/IGF-1 signalling (Refs.[15,16]). Indeed, heterozygous genetic inactivation of $p 110 \alpha$ leads to insulin resistance and glucose intolerance in young mice[15]. Interestingly, upon ageing, the heterozygous genetic inactivation of $p 110 \alpha$ leads to better overall glucose homeostasis compared to that in control aged mice[17]. Similarly, sustained low-level pharmacological inactivation of $\mathrm{p} 110 \alpha$ (together with $\mathrm{p} 110 \delta$ ) reduces obesity and ameliorates metabolic syndrome in obese mice and monkeys[18], uncovering pharmacological inhibition of $\mathrm{PI} 3 \mathrm{~K} / \mathrm{p} 110 \alpha$ as a potential anti-obesity intervention.

\section{PI3K $\beta$}

$\mathrm{p} 110 \beta$, the catalytic subunit of PI3K $\beta$, also has a broad tissue distribution but is absent or expressed at low levels in some cell types, such as B- and T-lymphocytes (Ref.[19] and Klaus Okkenhaug, personal communication).

p110 $\beta$ was the target of one of the first developed isoform-selective PI3K inhibitors[20], namely for antithrombotic therapy. p110 $\beta$ plays a specific role downstream of collagen and integrin receptors in platelet aggregation and $\mathrm{p} 110 \beta$ inhibitors interfere with thrombosis without inducing bleeding[20-22]; reviewed in Ref.[23]).

Recently, mutations similar to those in PIK3CA have also been found in PIK3CB (the gene for $\mathrm{p} 110 \beta)$ in cancer, albeit at a much lower frequency[24,25]. It is important to keep in mind that nonmutated $p 110 \beta$ could be activated by mutations in $p 85$ (Ref.[26]). PI3K $\beta$ has been reported to be the main mediator of enhanced PI3K activity induced upon the inactivation and loss of PTEN in cancer (reviewed in Ref.[14]), but this appears to be dependent on the genetic context, as PI3K $\alpha$ (Ref.[27,28]) and PI3Kס (Ref.[29]) are also capable of contributing to biology induced by PTEN loss.

There is increasing evidence for a role of PI3K $\beta$ in prostate cancer, in which PTEN inactivation is a common event. PI3K $\beta$ has been shown to positively regulate androgen receptor transactivation in prostate cancer cell lines[30] as well as in Sertoli cells in the regulation of mouse fertility[31]. In line with the contribution of PI3K $\beta$ and PI3Kס (Ref.[29]) to enhanced PI3K activity upon PTEN loss, a $\mathrm{PI} 3 \mathrm{~K} \beta / \delta$ inhibitor was found to be very effective in a preclinical study of prostate cancer, particularly in combination with hormonal therapy[32]. Another study[33] showed that the combined inhibition of PI3K $\alpha / \beta$ and androgen receptor is effective at inhibiting PTEN mutant prostate cancer cells.

$p 110 \beta$ is highly expressed in myeloid cells in which it has been shown to regulate Fcy receptordriven responses, in concert with p110 $\delta$ under certain conditions (Refs.[34,35]). This could be exploited in the context of inflammatory disorders resulting from the deposition of immune complexes, which, when not cleared effectively, lead to tissue damage and non-resolving inflammation. This therapeutic potential for $p 110 \beta$ inhibition is illustrated by the observation that mice lacking PI3K $\beta$ activity are protected in an experimental model of autoimmune skin blistering disease[34]. 


\section{PI3K}

p1108, like p110 $\gamma$, is highly expressed in leukocytes[36,37] but is also present at intermediate levels in other tissues, such as neurons[38] and some transformed epithelial cells[39,40]. Its predominant expression in the haematopoietic compartment correlates with a variety of immune functions, mainly in the adaptive immune system, with important roles in B- and T-cells[41], but also in mast cells[42] and myeloid cells (such as neutrophils and macrophages)[43,34].

Recently, germline mutations in PIK3CD have been identified in a rare disease called APDS

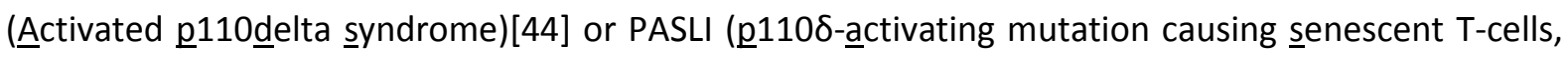
lymphadenopathy and immunodeficiency)[45] (reviewed in Ref.[46]). This disease is an autosomallydominant primary immune deficiency, which often (but not always) predisposes to respiratory infections and airway damage, and can lead to early death from infection-related causes and possibly lymphoma. The PIK3CD mutations in APDS are similar to the hot-spot mutations found in PIK3CA in that they activate the p110ס kinase. These patients could therefore benefit from the use of p1108-selective inhibitors.

Apart from a very low frequency mutation found in diffuse large B-cell lymphoma[47], the PIK3CD gene is mostly non-mutated in cancer. Like wild-type $p 110 \alpha$ and $p 110 \beta, p 110 \delta$ may become activated by mutations in its associated p85 regulatory subunit[26]. Whereas the expression level of p110 in leukocytes does not appear to significantly increase upon transformation, some solid tumour cell lines express high levels of the p110 protein, where it might contribute to migration and epithelial polarity[48,39,40,49,50].

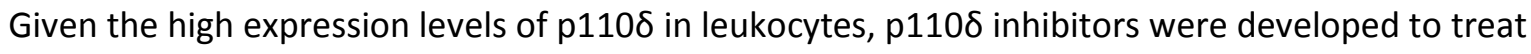
blood cancers in the hope that they would induce an anti-proliferative/cytotoxic effect across all haematological malignancies. However, the cytotoxic/cytostatic effects of p110 inhibitors in transformed leukocytes turned out to be modest, at least in vitro. Despite this, p110 $\delta$ inhibitors have shown impressive clinical impact in some human B-cell malignancies, such as CLL, and a PI3Kס inhibitor (Idelalisib/Zydelig) from Gilead is the first approved (2014) PI3K inhibitor[51]. The mechanism of action of PI3K inhibition in B-cell malignancies is based on interference with signalling by stimuli from the B-cell antigen receptor, co-stimulatory receptors, adhesion receptors and chemokines, on which some B-cell malignancies depend (reviewed in Ref.[52]). There is no evidence for a direct cytotoxic effect of PI3K $\delta$ inhibition on leukaemic cells in patients.

An interesting recent finding is that inhibition of PI3K $\delta$ can stimulate immune responses against solid tumours, thereby broadening the utility of PI3K $\delta$ inhibitors in cancer treatment beyond haematological malignancies[53], a concept that will be tested in human clinical trials in the near future (NCT02540928 and NCT02468557 on ClinicalTrials.gov). Mechanistically, inhibition of PI3K in cancer preferentially reduces the immune-suppressive function of regulatory T-cells, allowing an anti-tumour cytotoxic T-cell response to develop[53]. PI3K $\delta$ inhibition also dampens myeloid-derived suppressor cells in cancer[53]. As a potential therapeutic approach, it would be interesting to combine PI3K $\delta$ inhibitors with surgery (which allows the immune system to deal with micrometastases once the primary tumour is resected, as was demonstrated in Ref.[53]), irradiation (which can generate neo-antigens) or other immuno-modulatory agents, such as immune checkpoint blockers or tumour vaccines.

\section{PI3KY}

As for $\mathrm{p} 110 \delta$, expression of this PI3K isoform is enriched in leukocytes, in which it mainly regulates the innate immune system. The literature on $\mathrm{p} 110 \mathrm{p}$ is complex, as it describes both scaffold- 
dependent and -independent roles of this PI3K. Below, we summarize what is known about the kinase-dependent roles of $\mathrm{p} 110 \mathrm{y}$.

There are multiple immune-related disease indications for $\mathrm{p} 110 \mathrm{y}$ (Table I; reviewed in Refs.[54,55]) but it has turned out to be challenging to make truly isoform-selective inhibitors for this PI3K. This means that the early promise of p110y as a drug target in disease[56] has not (yet) been fulfilled.

Other than in leukocytes, p110y is also expressed at low levels (compared to leukocytes) in cardiomyocytes, smooth muscle cells and endothelial cells. Interplay between all these p110 expressing cells has been implicated in cardiovascular biology. Indeed, interference with p110 $\gamma$ activity could be beneficial in cardiovascular disease under certain conditions, for example by alleviating myocardial inflammation and preventing maladaptive matrix remodelling (for a review, see Ref.[57]).

Whereas a cancer-cell-intrinsic role for $\mathrm{p} 110 \mathrm{\gamma}$ has not been clearly established, a role for this PI3K isoform in cancer-associated inflammation is emerging[58]. Indeed, p110 $\gamma$ regulates the recruitment and activation of myeloid cells by diverse tumour-derived stimuli, allowing these cells to invade into the tumour and stimulate tumour angiogenesis, growth and progression[58].

\section{Interference with PI3K activity in disease: isoform-selective or multi-PI3K-targeted inhibitors?}

PI3Ks play important roles in normal physiology and therefore identifying a suitable therapeutic window of PI3K inhibition at the organismal level is an important issue. This is disease-dependent, with different toxicity profiles accepted for example in cancer versus in more chronic conditions, such as in inflammatory, auto-immune and metabolic disorders.

Pharma has been very effective in developing a range of inhibitors that target single or multiple PI3K isoforms. Given the importance of PI3K in cell biology, a consideration has been the toxicity profile of pan-class I PI3K isoform inhibitors. These have turned out to be reasonably well tolerated in a cancer setting, although the level of on-target inhibition that was achieved in these trials has not always been fully established. Toxicity of isoform-selective PI3K inhibitors is generally expected to be less wide-ranging than that of pan-PI3K inhibitors, allowing tolerance of higher drug doses, resulting in more complete PI3K target inhibition. However, as illustrated by the colitis induced by long-term PI3Kס inhibition in CLL patients[59], drug tolerability can be an issue upon interference with a single $\mathrm{PI3K}$ isoform, as a result of mechanism-based, on-target side effects. Potential ways to overcome this is through topical application of a PI3K inhibitor, as exemplified by the ongoing development of an inhaled PI3Kס inhibitor by GSK as an anti-inflammatory agent for the treatment of inflammatory airway diseases[60,61], avoiding systemic exposure to the drug.

PI3K isoforms can also cooperate, especially under physiological conditions where cells are exposed to multiple stimuli, simultaneously signalling through different types of receptors. For example, some immune functions of $\mathrm{p} 110 \delta$ are executed in concert with other class I PI3K isoforms, such as with $\mathrm{p} 110 \mathrm{p}$ in the respiratory burst of human neutrophils[43] or with $\mathrm{p} 110 \beta$ in FcRp receptor signalling[34,35]. This interplay between class I PI3K isoforms in inflammation and immunity is complex (reviewed in Refs. $[62,54,63,64]$ ) and therapeutically explored by the ongoing development of dual PI3K inhibitors, such as dual PI3K $\beta / \delta$ or dual PI3K $\gamma / \delta$ (IPI-145; Duvelesib)[65] inhibitors. A risk 
of this strategy is the induction of overwhelming immune suppression, especially in cancer trial settings in which patients may have previously undergone immune-compromising therapies.

PI3K isoforms can also compensate for each other, as best documented in cancer. A key way in which this phenomenon arises is through feedback mechanisms: these regulatory loops exist to counterbalance the PI3K pathway that is inhibited by an isoform-selective PI3K inhibitor, and lead to the activation of the remaining, non-inhibited PI3K isoform(s). Recently published examples include the 'rebound' of PI3K $\alpha$ activity upon blockade of PI3K $\beta$ (Refs.[48,33]). These data suggest that the use of pan-class I PI3K inhibitors may be needed to counterbalance class I PI3K-dependent compensatory mechanisms developed by cancer cells. Another key consideration for using PI3K inhibitors for cancer treatment is the finding that cells can survive and proliferate with very low levels of class I PI3K activity[66]. Moreover, because PI3K $\alpha$ is critical for insulin signalling, a serious problem upon administration of PI3K inhibitors is the compensatory, increased systemic insulin production, which can stimulate cancer cell proliferation. Of course, upon sufficient inhibition of PI3K activity in the cancer cells, their responsiveness to insulin-stimulated PI3K would be expected to be blocked, but insulin could still activate other signalling pathways in the cancer cells, such as MAPK.

\section{Conclusion}

Despite extensive PI3K drug development efforts, only one PI3K inhibitor (Idelasib/Zydelig against PI3Kס, for use in some B-cell malignancies) has been approved for human therapy to date[51], but this is expected to change in the near future, especially as part of combination therapies in cancer. Indeed, some promising combination treatments with PI3K inhibitors have recently been reported, such as with inhibitors of PARP (reviewed in Ref.[67]) or CDK4/6 (Ref.[68]) in breast cancer. Another exciting example is the observation that PI3K $\alpha$ inhibitors can enhance the responsiveness of oestrogen receptor-positive breast cancer cells to hormone therapy[69]. The exploitation of the roles that PI3Ks play in the immune system is also likely to be a further fertile area of drug development, not only in chronic inflammation as initially intended (mainly PI3KY and PI3Kס), but also in cancer, such as in immunotherapy (PI3K $)$ or modulation of cancer-induced inflammation (PI3KY). The use of PI3K inhibitors to interfere with angiogenesis[70] in cancer, for example by modulating the tumour microvasculature to increase chemotherapy delivery[71], remains to be more extensively explored.

Acknowledgements Work in the laboratory of B.V. was supported by Cancer Research UK [C23338/A15965], the UK Biotechnology and Biological Sciences Research Council [BB/I007806/1], the Ludwig Institute for Cancer Research, and the National Institute for Health Research (NIHR) University College London Hospitals Biomedical Research Centre.

The authors apologize to those authors whose work could not be cited due to space constraints.

Competing interests BV is a consultant to Karus Therapeutics (Oxford, UK). 
Vanhaesebroeck et al. - 7

Figure Legend: Shown are the different classes and isoforms of PI3K, their generic roles in cell biology and potential disease implications. 
Table I - Therapeutic indications for class I PI3K isoforms: Key indications for interference with selected PI3K isoforms in disease. This is an oversimplification, given that PI3K isoforms could be targeted in combination, as described in more detail in the main text.

\begin{tabular}{|c|c|c|c|}
\hline PI3K $\alpha$ & PI3K $\beta$ & PI3Kס & PI3K \\
\hline $\begin{array}{l}\text { - Solid tumours } \\
\text { - Overgrowth } \\
\text { syndromes } \\
\text { - Obesity, metabolic } \\
\text { syndrome }\end{array}$ & $\begin{array}{l}\text { - Solid tumours (PTEN } \\
\text { null?) } \\
\text { - Thrombosis } \\
\text { - Inflammation: } \\
\text { antigen/antibody } \\
\text { immune complex- } \\
\text { driven immune } \\
\text { dysfunction }\end{array}$ & $\begin{array}{l}\text { - } \\
\text { B-cell malignancies } \\
\text { (through immune } \\
\text { stimulation) } \\
\text { - } \text { Autoimmunity/inflammatory } \\
\text { disorders (rheumatoid } \\
\text { arthritis, allergy, airway } \\
\text { inflammation, ...) } \\
\text { - Activated } \\
\text { p110delta } \\
\text { Syndrome }\end{array}$ & $\begin{array}{ll}\text { - } & \text { Inflammatory } \\
\text { disorders } \\
\text { (rheumatoid } \\
\text { arthritis, allergy, } \\
\text { airway } \\
\text { inflammation, } \\
\text { obesity-related } \\
\text { inflammation, } \\
\text { atherosclerosis, ...) } \\
\text { Cardiovascular } \\
\text { disease } \\
\text { Cancer-associated } \\
\text { inflammation }\end{array}$ \\
\hline
\end{tabular}




\section{References}

1. Vanhaesebroeck B, Ali K, Bilancio A, Geering B, Foukas LC (2005) Signalling by PI3K isoforms: insights from gene-targeted mice. Trends Biochem Sci 30 (4):194-204

2. Hirsch E, Braccini L, Ciraolo E, Morello F, Perino A (2009) Twice upon a time: PI3K's secret double life exposed. Trends Biochem Sci 34 (5):244-248

3. Alliouachene S, Bilanges B, Chicanne G, Anderson KE, Pearce W, Ali K, Valet C, Posor Y, Low PC, Chaussade $C$ et al. (2015) Inactivation of the class II PI3K-C2 $\beta$ potentiates insulin signaling and sensitivity. Cell reports Accepted for publication ( ):

4. Bilanges B, Vanhaesebroeck B (2014) Cinderella finds her shoe: the first Vps34 inhibitor uncovers a new PI3K-AGC protein kinase connection. Biochem J 464 (2):e7-10

5. Burke JE, Perisic O, Masson GR, Vadas O, Williams RL (2012) Oncogenic mutations mimic and enhance dynamic events in the natural activation of phosphoinositide 3-kinase p110alpha (PIK3CA). Proc Natl Acad Sci U S A 109 (38):15259-15264

6. Kurek KC, Luks VL, Ayturk UM, Alomari Al, Fishman SJ, Spencer SA, Mulliken JB, Bowen ME, Yamamoto GL, Kozakewich HP et al. (2012) Somatic mosaic activating mutations in PIK3CA cause CLOVES syndrome. American journal of human genetics 90 (6):1108-1115

7. Lindhurst MJ, Parker VE, Payne F, Sapp JC, Rudge S, Harris J, Witkowski AM, Zhang Q, Groeneveld MP, Scott CE et al. (2012) Mosaic overgrowth with fibroadipose hyperplasia is caused by somatic activating mutations in PIK3CA. Nat Genet 44 (8):928-933

8. Riviere JB, Mirzaa GM, O'Roak BJ, Beddaoui M, Alcantara D, Conway RL, St-Onge J, Schwartzentruber JA, Gripp KW, Nikkel SM et al. (2012) De novo germline and postzygotic mutations in AKT3, PIK3R2 and PIK3CA cause a spectrum of related megalencephaly syndromes. Nature genetics $44(8): 934-940$

9. Lee JH, Huynh M, Silhavy JL, Kim S, Dixon-Salazar T, Heiberg A, Scott E, Bafna V, Hill KJ, Collazo A et al. (2012) De novo somatic mutations in components of the PI3K-AKT3-mTOR pathway cause hemimegalencephaly. Nature genetics 44 (8):941-945

10. Keppler-Noreuil KM, Sapp JC, Lindhurst MJ, Parker VE, Blumhorst C, Darling T, Tosi LL, Huson SM, Whitehouse RW, Jakkula E et al. (2014) Clinical delineation and natural history of the PIK3CA-related overgrowth spectrum. American journal of medical genetics Part A 164 (7):1713-1733

11. Van Keymeulen A, Lee MY, Ousset M, Brohee S, Rorive S, Giraddi RR, Wuidart A, Bouvencourt G, Dubois C, Salmon I et al. (2015) Reactivation of multipotency by oncogenic PIK3CA induces breast tumour heterogeneity. Nature 525 (7567):119-123

12. Koren S, Reavie L, Couto JP, De Silva D, Stadler MB, Roloff T, Britschgi A, Eichlisberger T, Kohler H, Aina $O$ et al. (2015) PIK3CA(H1047R) induces multipotency and multi-lineage mammary tumours. Nature 525 (7567):114-118

13. Fritsch C, Huang A, Chatenay-Rivauday C, Schnell C, Reddy A, Liu M, Kauffmann A, Guthy D, Erdmann D, De Pover A et al. (2014) Characterization of the novel and specific PI3Kalpha inhibitor NVP-BYL719 and development of the patient stratification strategy for clinical trials. Mol Cancer Ther $13(5): 1117-1129$

14. Weigelt B, Downward J (2012) Genomic Determinants of PI3K Pathway Inhibitor Response in Cancer. Frontiers in oncology 2:109

15. Foukas LC, Claret M, Pearce W, Okkenhaug K, Meek S, Peskett E, Sancho S, Smith AJ, Withers DJ, Vanhaesebroeck B (2006) Critical role for the p110alpha phosphoinositide-3-OH kinase in growth and metabolic regulation. Nature 441 (7091):366-370

16. Knight ZA, Gonzalez B, Feldman ME, Zunder ER, Goldenberg DD, Williams O, Loewith R, Stokoe D, Balla A, Toth B et al. (2006) A pharmacological map of the PI3-K family defines a role for p110alpha in insulin signaling. Cell 125 (4):733-747

17. Foukas LC, Bilanges B, Bettedi L, Pearce W, Ali K, Sancho S, Withers DJ, Vanhaesebroeck B (2013) Long-term p110alpha PI3K inactivation exerts a beneficial effect on metabolism. EMBO molecular medicine 5 (4):563-571 
18. Ortega-Molina A, Lopez-Guadamillas E, Mattison JA, Mitchell SJ, Munoz-Martin M, Iglesias G, Gutierrez VM, Vaughan KL, Szarowicz MD, Gonzalez-Garcia I et al. (2015) Pharmacological inhibition of PI3K reduces adiposity and metabolic syndrome in obese mice and rhesus monkeys. Cell Metab 21 (4):558-570

19. Ramadani F, Bolland DJ, Garcon F, Emery JL, Vanhaesebroeck B, Corcoran AE, Okkenhaug K (2010) The PI3K isoforms p110alpha and p110delta are essential for pre-B cell receptor signaling and B cell development. Sci Signal 3 (134):ra60

20. Jackson SP, Schoenwaelder SM, Goncalves I, Nesbitt WS, Yap CL, Wright CE, Kenche V, Anderson KE, Dopheide SM, Yuan Y et al. (2005) PI 3-kinase p110beta: a new target for antithrombotic therapy. Nat Med 11 (5):507-514

21. Giordanetto F, Wallberg A, Ghosal S, Iliefski T, Cassel J, Yuan ZQ, von Wachenfeldt H, Andersen SM, Inghardt T, Tunek A et al. (2012) Discovery of phosphoinositide 3-kinases (PI3K) p110beta isoform inhibitor 4-[2-hydroxyethyl(1-naphthylmethyl)amino]-6-[(2S)-2-methylmorpholin-4-yl]-1Hpyri midin-2-one, an effective antithrombotic agent without associated bleeding and insulin resistance. Bioorg Med Chem Lett 22 (21):6671-6676

22. Nylander S, Wagberg F, Andersson M, Skarby T, Gustafsson D (2015) Exploration of efficacy and bleeding with combined phosphoinositide 3-kinase beta inhibition and aspirin in man. J Thromb Haemost 13 (8):1494-1502

23. Laurent PA, Severin S, Gratacap MP, Payrastre B (2014) Class I PI 3-kinases signaling in platelet activation and thrombosis: PDK1/Akt/GSK3 axis and impact of PTEN and SHIP1. Advances in biological regulation 54:162-174

24. Pazarentzos E, Giannikopoulos P, Hrustanovic G, St John J, Olivas VR, Gubens MA, Balassanian R, Weissman J, Polkinghorn W, Bivona TG (2015) Oncogenic activation of the PI3-kinase p110beta isoform via the tumor-derived PIK3Cbeta kinase domain mutation. Oncogene

25. Robinson D, Van Allen EM, Wu YM, Schultz N, Lonigro RJ, Mosquera JM, Montgomery B, Taplin ME, Pritchard CC, Attard G et al. (2015) Integrative clinical genomics of advanced prostate cancer. Cell 161 (5):1215-1228

26. Jaiswal BS, Janakiraman V, Kljavin NM, Chaudhuri S, Stern HM, Wang W, Kan Z, Dbouk HA, Peters $B A$, Waring $P$ et al. (2009) Somatic mutations in p85alpha promote tumorigenesis through class IA PI3K activation. Cancer Cell 16 (6):463-474

27. Berenjeno IM, Guillermet-Guibert J, Pearce W, Gray A, Fleming S, Vanhaesebroeck B (2012) Both p110alpha and p110beta isoforms of PI3K can modulate the impact of loss-of-function of the PTEN tumour suppressor. Biochem J 442 (1):151-159

28. Schmit F, Utermark T, Zhang S, Wang Q, Von T, Roberts TM, Zhao JJ (2014) PI3K isoform dependence of PTEN-deficient tumors can be altered by the genetic context. Proc Natl Acad Sci U S A 111 (17):6395-6400

29. Jiang X, Chen S, Asara JM, Balk SP (2010) Phosphoinositide 3-kinase pathway activation in phosphate and tensin homolog (PTEN)-deficient prostate cancer cells is independent of receptor tyrosine kinases and mediated by the p110beta and p110delta catalytic subunits. J Biol Chem 285 (20):14980-14989

30. Zhu Q, Youn H, Tang J, Tawfik O, Dennis K, Terranova PF, Du J, Raynal P, Thrasher JB, Li B (2008) Phosphoinositide $3-\mathrm{OH}$ kinase p85alpha and p110beta are essential for androgen receptor transactivation and tumor progression in prostate cancers. Oncogene 27 (33):4569-4579

31. Guillermet-Guibert J, Smith LB, Halet G, Whitehead MA, Pearce W, Rebourcet D, Leon K, Crepieux P, Nock G, Stromstedt M et al. (2015) Novel Role for p110beta PI 3-Kinase in Male Fertility through Regulation of Androgen Receptor Activity in Sertoli Cells. PLoS Genet 11 (7):e1005304

32. Marques RB, Aghai A, de Ridder CM, Stuurman D, Hoeben S, Boer A, Ellston RP, Barry ST, Davies BR, Trapman J et al. (2015) High Efficacy of Combination Therapy Using PI3K/AKT Inhibitors with Androgen Deprivation in Prostate Cancer Preclinical Models. European urology 67 (6):1177-1185 
33. Schwartz S, Wongvipat J, Trigwell CB, Hancox U, Carver BS, Rodrik-Outmezguine V, Will M, Yellen P, de Stanchina E, Baselga J et al. (2015) Feedback suppression of PI3Kalpha signaling in PTENmutated tumors is relieved by selective inhibition of PI3Kbeta. Cancer Cell 27 (1):109-122

34. Kulkarni S, Sitaru C, Jakus Z, Anderson KE, Damoulakis G, Davidson K, Hirose M, Juss J, Oxley D, Chessa TA et al. (2011) PI3Kbeta plays a critical role in neutrophil activation by immune complexes. Sci Signal 4 (168):ra23

35. Leverrier Y, Okkenhaug K, Sawyer C, Bilancio A, Vanhaesebroeck B, Ridley AJ (2003) Class I phosphoinositide 3-kinase p110beta is required for apoptotic cell and Fcgamma receptor-mediated phagocytosis by macrophages. J Biol Chem 278 (40):38437-38442

36. Vanhaesebroeck B, Welham MJ, Kotani K, Stein R, Warne PH, Zvelebil MJ, Higashi K, Volinia S, Downward J, Waterfield MD (1997) P110delta, a novel phosphoinositide 3-kinase in leukocytes. Proc Natl Acad Sci U S A 94 (9):4330-4335

37. Chantry D, Vojtek A, Kashishian A, Holtzman DA, Wood C, Gray PW, Cooper JA, Hoekstra MF (1997) p110delta, a novel phosphatidylinositol 3-kinase catalytic subunit that associates with p85 and is expressed predominantly in leukocytes. J Biol Chem 272 (31):19236-19241

38. Eickholt BJ, Ahmed Al, Davies M, Papakonstanti EA, Pearce W, Starkey ML, Bilancio A, Need AC, Smith AJ, Hall SM et al. (2007) Control of axonal growth and regeneration of sensory neurons by the p110delta PI 3-kinase. PLoS One 2 (9):e869

39. Sawyer C, Sturge J, Bennett DC, O'Hare MJ, Allen WE, Bain J, Jones GE, Vanhaesebroeck B (2003) Regulation of breast cancer cell chemotaxis by the phosphoinositide 3-kinase p110delta. Cancer Res 63 (7):1667-1675

40. Tzenaki N, Andreou M, Stratigi K, Vergetaki A, Makrigiannakis A, Vanhaesebroeck B, Papakonstanti EA (2012) High levels of p110delta PI3K expression in solid tumor cells suppress PTEN activity, generating cellular sensitivity to p110delta inhibitors through PTEN activation. FASEB J 26 (6):2498-2508

41. Okkenhaug K, Bilancio A, Farjot G, Priddle H, Sancho S, Peskett E, Pearce W, Meek SE, Salpekar A, Waterfield MD et al. (2002) Impaired B and T cell antigen receptor signaling in p110delta PI 3-kinase mutant mice. Science (New York, NY 297 (5583):1031-1034

42. Ali K, Bilancio A, Thomas M, Pearce W, Gilfillan AM, Tkaczyk C, Kuehn N, Gray A, Giddings J, Peskett E et al. (2004) Essential role for the p110delta phosphoinositide 3-kinase in the allergic response. Nature 431 (7011):1007-1011

43. Condliffe AM, Davidson K, Anderson KE, Ellson CD, Crabbe T, Okkenhaug K, Vanhaesebroeck B, Turner M, Webb L, Wymann MP et al. (2005) Sequential activation of class IB and class IA PI3K is important for the primed respiratory burst of human but not murine neutrophils. Blood 106 (4):1432-1440

44. Angulo I, Vadas O, Garcon F, Banham-Hall E, Plagnol V, Leahy TR, Baxendale H, Coulter T, Curtis J, Wu C et al. (2013) Phosphoinositide 3-kinase delta gene mutation predisposes to respiratory infection and airway damage. Science (New York, NY 342 (6160):866-871

45. Lucas CL, Kuehn HS, Zhao F, Niemela JE, Deenick EK, Palendira U, Avery DT, Moens L, Cannons JL, Biancalana $\mathrm{M}$ et al. (2014) Dominant-activating germline mutations in the gene encoding the $\mathrm{PI}(3) \mathrm{K}$ catalytic subunit p110delta result in T cell senescence and human immunodeficiency. Nat Immunol $15(1): 88-97$

46. Coulter T, Chandra A, Bacon CM, Babar J, Curtis J, Farmer G, Steele CL, Leahy TR, Doffinger R, Baxendale $\mathrm{H}$ et al. (2015) The broad clinical spectrum and unexpected features of Activated PI3kinase Delta Syndrome; large patient cohort study. Submitted for publication

47. Zhang J, Grubor V, Love CL, Banerjee A, Richards KL, Mieczkowski PA, Dunphy C, Choi W, Au WY, Srivastava $G$ et al. (2013) Genetic heterogeneity of diffuse large B-cell lymphoma. Proc Natl Acad Sci U S A 110 (4):1398-1403

48. Costa C, Ebi H, Martini M, Beausoleil SA, Faber AC, Jakubik CT, Huang A, Wang Y, Nishtala M, Hall $B$ et al. (2015) Measurement of PIP3 levels reveals an unexpected role for p110beta in early adaptive responses to p110alpha-specific inhibitors in luminal breast cancer. Cancer Cell 27 (1):97-108 
49. Peng J, Awad A, Sar S, Hamze Komaiha O, Moyano R, Rayal A, Samuel D, Shewan A, Vanhaesebroeck B, Mostov K et al. (2015) Phosphoinositide 3-kinase p110delta promotes lumen formation through the enhancement of apico-basal polarity and basal membrane organization. Nature communications 6:5937

50. Tzenaki N, Papakonstanti EA (2013) p110delta PI3 kinase pathway: emerging roles in cancer. Frontiers in oncology 3:40

51. Vanhaesebroeck B, Khwaja A (2014) PI3Kdelta inhibition hits a sensitive spot in B cell malignancies. Cancer Cell 25 (3):269-271

52. Okkenhaug K, Burger JA (2015) PI3K Signaling in Normal B Cells and Chronic Lymphocytic Leukemia (CLL). Curr Top Microbiol Immunol

53. Ali K, Soond DR, Pineiro R, Hagemann T, Pearce W, Lim EL, Bouabe H, Scudamore CL, Hancox T, Maecker $\mathrm{H}$ et al. (2014) Inactivation of PI(3)K p110delta breaks regulatory T-cell-mediated immune tolerance to cancer. Nature 510 (7505):407-411

54. Hawkins PT, Stephens LR (2015) PI3K signalling in inflammation. Biochim Biophys Acta 1851 (6):882-897

55. Costa C, Martin-Conte EL, Hirsch E (2011) Phosphoinositide 3-kinase p110gamma in immunity. IUBMB life 63 (9):707-713

56. Ruckle T, Schwarz MK, Rommel C (2006) PI3Kgamma inhibition: towards an 'aspirin of the 21st century'? Nat Rev Drug Discov 5 (11):903-918

57. Ghigo A, Morello F, Perino A, Hirsch E (2013) Therapeutic applications of PI3K inhibitors in cardiovascular diseases. Future medicinal chemistry 5 (4):479-492

58. Schmid MC, Avraamides CJ, Dippold HC, Franco I, Foubert P, Ellies LG, Acevedo LM, Manglicmot JR, Song X, Wrasidlo W et al. (2011) Receptor tyrosine kinases and TLR/IL1Rs unexpectedly activate myeloid cell PI3kgamma, a single convergent point promoting tumor inflammation and progression. Cancer Cell 19 (6):715-727

59. Coutre SE, Barrientos JC, Brown JR, de Vos S, Furman RR, Keating MJ, Li D, O'Brien SM, Pagel JM, Poleski MH et al. (2015) Management of adverse events associated with idelalisib treatment: expert panel opinion. Leuk Lymphoma:1-8

60. Wilson R, Cahn A, Deans A, McSherry I, Rambaran C, Sousa A, Wilbraham D (2013) Safety, tolerability and pharmacokinetics (PK) of single and repeat nebulised doses of a novel phosphoinositide 3-kinase $\delta$ inhibitor (PI3Kס), GSK2269557, administered to healthy male subjects in a phase I study. ERJ 42 Suppl 57

61. Wassef M, Blei F, Adams D, Alomari A, Baselga E, Berenstein A, Burrows P, Frieden IJ, Garzon MC, Lopez-Gutierrez JC et al. (2015) Vascular Anomalies Classification: Recommendations From the International Society for the Study of Vascular Anomalies. Pediatrics 136 (1):e203-214

62. Okkenhaug K (2013) Signaling by the phosphoinositide 3-kinase family in immune cells. Annu Rev Immunol 31:675-704

63. Banham-Hall E, Clatworthy MR, Okkenhaug K (2012) The Therapeutic Potential for PI3K Inhibitors in Autoimmune Rheumatic Diseases. The open rheumatology journal 6:245-258

64. So L, Fruman DA (2012) PI3K signalling in B- and T-lymphocytes: new developments and therapeutic advances. Biochem J 442 (3):465-481

65. Winkler DG, Faia KL, DiNitto JP, Ali JA, White KF, Brophy EE, Pink MM, Proctor JL, Lussier J, Martin CM et al. (2013) PI3K-delta and PI3K-gamma inhibition by IPI-145 abrogates immune responses and suppresses activity in autoimmune and inflammatory disease models. Chem Biol 20 (11):1364-1374

66. Foukas LC, Berenjeno IM, Gray A, Khwaja A, Vanhaesebroeck B (2010) Activity of any class IA PI3K isoform can sustain cell proliferation and survival. Proc Natl Acad Sci U S A 107 (25):11381-11386

67. Rehman FL, Lord CJ, Ashworth A (2012) The promise of combining inhibition of PI3K and PARP as cancer therapy. Cancer discovery 2 (11):982-984

68. Vora SR, Juric D, Kim N, Mino-Kenudson M, Huynh T, Costa C, Lockerman EL, Pollack SF, Liu M, Li $X$ et al. (2014) CDK 4/6 inhibitors sensitize PIK3CA mutant breast cancer to PI3K inhibitors. Cancer Cell 26 (1):136-149 
69. Bosch A, Li Z, Bergamaschi A, Ellis H, Toska E, Prat A, Tao JJ, Spratt DE, Viola-Villegas NT, Castel P et al. (2015) PI3K inhibition results in enhanced estrogen receptor function and dependence in hormone receptor-positive breast cancer. Science translational medicine 7 (283):283ra251

70. Graupera M, Potente M (2013) Regulation of angiogenesis by PI3K signaling networks. Exp Cell Res 319 (9):1348-1355

71. Qayum N, Im J, Stratford MR, Bernhard EJ, McKenna WG, Muschel RJ (2012) Modulation of the tumor microvasculature by phosphoinositide-3 kinase inhibition increases doxorubicin delivery in vivo. Clin Cancer Res 18 (1):161-169 
class I

\section{\begin{tabular}{llll}
$\mathrm{PI} 3 \mathrm{~K} \alpha$ & $\mathrm{PI} 3 \mathrm{~K} \beta$ & $\mathrm{PI} 3 \mathrm{~K} \delta$ & $\mathrm{PI} 3 \mathrm{~K} \gamma$ \\
\hline
\end{tabular}}

SIGNAL TRANSDUCTION

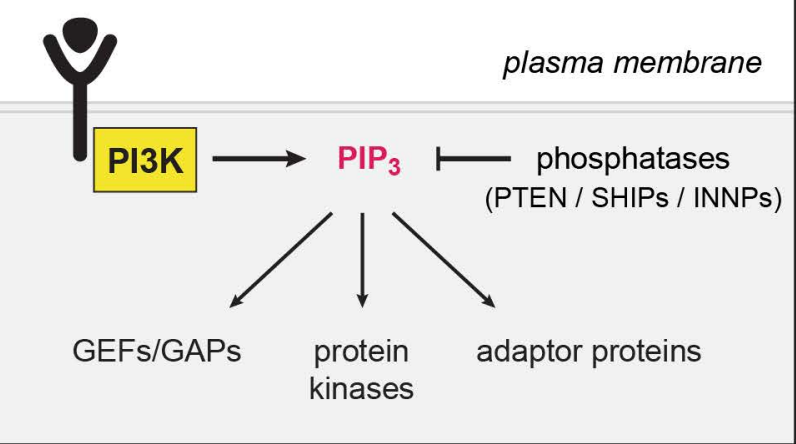

cancer, overgrowth, metabolic syndromes, thrombosis, autoimmunity \& inflammation class II

class III

\section{\begin{tabular}{|l|l|l|l|l|}
\hline PI3K-C2 $\alpha$ & PI3K-C2 $\beta$ & PI3K-C2 $\gamma \quad$ Vps34 \\
\hline
\end{tabular}}

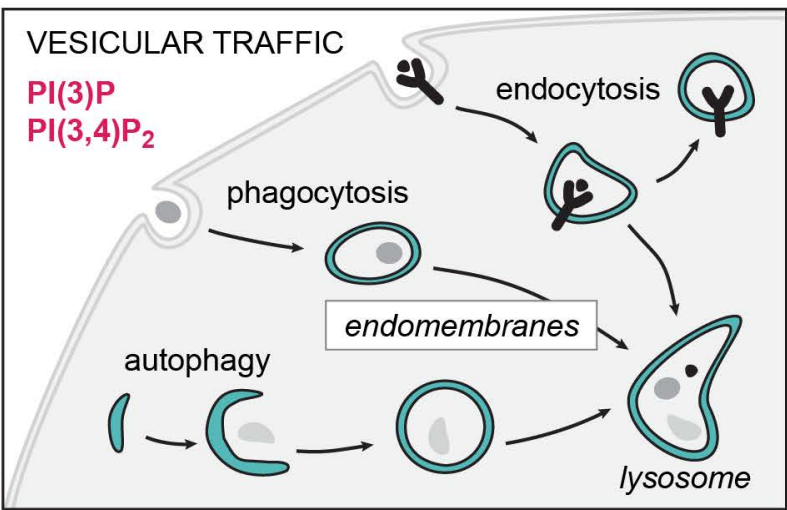

disease indications: ? 